\title{
From Noble Dress to Jewish Attire: Jewish Appearances in the Polish-Lithuanian Commonwealth and the Holy Roman Empire
}

\begin{abstract}
This article examines the different styles of attire that had emerged by the eighteenth century among Jews in Poland and German-speaking lands. It argues that Jews in both regions developed their attire from older styles of dress that had fallen out of fashion among German burghers and Polish noblemen, respectively. Nevertheless, the distinguishability of Jews and Christians and distinctions among Jews according to social status, gender, and geographic origin were never clear-cut issues.
\end{abstract}

Picturing a Hasidic Jew in Jerusalem or New York today, with a long black coat, a silk or satin caftan on Sabbath, and a black (fur) hat, many believe that this or similar attire has been the typical dress of (East European) Jews throughout time. ${ }^{1}$ However, dress and appearance have always undergone continual change and are a rather fluid marker of identity and belonging. Though Jewish law traditionally prescribes that Jews be distinguishable from their non-Jewish neighbors, and Christian and Jewish authorities have since the thirteenth century explicitly stipulated distinctive dress, such normative prescriptions do not allow for the conclusion that Jewish men and women have always been recognizable by their dress. Likewise, the fact that Jews were sometimes forced to wear distinctive signs does not mean that they were otherwise invisible as Jews or could pass as Christians when not wearing a discriminatory sign. ${ }^{2}$ Nevertheless, by the end of the eighteenth century there seems to have been a clear sense of a "Jewish attire".

\footnotetext{
1 On today's Hasidic dress see: Eric Silverman: A Cultural History of Jewish Dress. London 2013, 112-131.

2 On discriminatory signs in late medieval Italy see: Flora Cassen: Marking the Jews in Renaissance Italy. Politics, Religion, and the Power of Symbols. Cambridge 2017. For passing as a non-Jew see for a modern example: Kerry Wallach: Passing Illusions. Jewish Visibility in Weimar Germany. Ann Arbor 2017.

¿ Open Access. (C) 2019 Cornelia Aust, published by De Gruyter. (c) BY-NC-ND This work is licensed under a Creative Commons Attribution-NonCommercial-NoDerivatives 4.0 International License.

https://doi.org/10.1515/9783110635942-006
} 
In this article, I trace some developments concerning the dress and appearance of Jews, mostly men, of the early modern period in German-speaking lands, with a particular emphasis on Fürth (near Nuremberg) in Middle Franconia and Frankfurt am Main, and compare them with similar developments in early modern Poland. ${ }^{3}$ I ask how and when such a general term like "Jewish attire" emerged and what it meant for those who wore so-called "Jewish attire" or "Jewish dress". Did they even conceive it as "Jewish dress"? Where and when did visual difference play a particular role? Looking at such different sources as sumptuary laws, inventories, "ethnographic" descriptions, and costume books, I sketch out a highly complex picture in which perceived differences intersected, not only between Jews and Christians, but also among Jews themselves, concerning, for example, socioeconomic status, gender, and geography.

\section{The External Perception of Jewish Dress}

The insistence of Christian and Jewish authorities that Jews and Christians should be easily distinguishable in their outward appearance points to the possibility that, by the thirteenth century, Jews and Christians could often not be easily told apart. ${ }^{4}$ Both the Fourth Lateran Council of 1215 and the thirteenth-century takkanot Shum - the ordinances of the three Jewish communities of Speyer, Worms, and Mainz in the Rhineland - insisted that Jews had to be visually distinguishable from their Christian neighbors. Regulations of religious, royal, and urban authorities following the Fourth Lateran Council usually insisted on distinctive signs, including different forms of yellow (or red) patch, or specific hats, while rabbinical and communal Jewish ordinances insisted more generally that Jewish men not cut their hair and beard like Christians, that Jews observe the biblical prohibition of sha'atnets (the mixing of wool and linen), and that they generally not dress like Christians. ${ }^{5}$ As Flora Cassen has shown, this

3 On the dress of Jewish women in the early modern period see: Cornelia Aust: Covering the Female Jewish Body. Dress and Dress Regulations in Early Modern Ashkenaz, in: Central Europe 17 (2019) [forthcoming].

4 In antiquity, however, Cohen argues that Jews were not visibly distinctive from their environment: Shaye J. D. Cohen: The Beginnings of Jewishness. Boundaries, Varieties, Uncertainties. Berkeley 1999, 27-28, 31-33.

5 Alfred Rubens: A History of Jewish Costume, 2nd ed. London 1973, 80-97. On the medieval Jewish hat see: Sara Lipton: Dark Mirror. The Medieval Origins of Anti-Jewish Iconography. New York 2014, 21-54; Naomi Lubrich: The Wandering Hat. Iterations of the Medieval Jewish 
insistence does not necessarily mean that Jews, whether local or foreign, were not recognizable. Locally, Jews were usually known to their neighbors and may have been recognizable by the language they spoke to each other. When traveling they may have behaved differently from Christians in specific situations, for example by not making the sign of the cross when passing statues of the Virgin Mary or other sacred objects. ${ }^{6}$

Turning eastward, we know relatively little about the kind of dress worn by Jews in sixteenth-century Poland. As in other regions, religious and political authorities tried to enforce the stigmatization of Jews through specific markers, as for example with the Breslau synod of 1267, which prescribed that Jews wear a specific hat. Although such hats are depicted in church windows and elsewhere, these images provide little information regarding what Jews actually did or did not wear. In 1538, the Polish Sejm in Piotrków took up the issue. The political authorities decreed:

As the Jews abolished an old custom, namely the sign, which allowed to distinguish them from the Christians, and as they began to wear exactly the same clothes as the Christians, so that they became unrecognizable among Christians: therefore We command that all Jews and each of them should further wear a beret, or a hat or another headgear in a bright, meaning yellow, color, everywhere in Our Kingdom.

The order further stated that travelers were exempted from this regulation and that it was permitted to remove or conceal all signs of this kind while traveling. ${ }^{7}$ This decree provides some hint that Polish Jews indeed dressed in similar clothes as their non-Jewish neighbors. Nevertheless, we can assume that Jews and non-Jews

Pointed Cap, in: Jewish History 29 (2015), 203-244. On the "yellow batch", its reach and some of the implications of wearing it see Flora Cassen's article in this volume. On the takkanot Shum: Rainer Josef Barzen: Die Schum-Gemeinden und ihre Rechtssatzungen. Geschichte und Wirkungsgeschichte, in: Pia Heberer and Ursula Reuter (eds.): Die SchUM-Gemeinden Speyer Worms - Mainz. Regensburg 2013, 23-35.

6 Cassen, Marking the Jews in Renaissance Italy, 99-102. On stigma signs see also: Robert Jütte: Stigma-Symbole. Kleidung als identitätsstiftendes Merkmal bei spätmittelalterlichen und frühneuzeitlichen Randgruppen (Juden, Dirnen, Aussätzige, Bettler), in: Saeculum (Zwischen Sein und Schein. Kleidung und Identität in der ständischen Gesellschaft) 44 (1993), 65-89.

7 De judaeis, Petrikov 1538, in: Jozafat Ohryzko (ed.): Volumina Legum: przedruk zbioru praw staraniem XX. pijarów w Warszawie, od roku 1732 do roku 1782 wydanego, vol. 1: Ab anno 1347 ad annum 1547, Warsaw 1980 [reprint of Petersburg 1859], no. 525, 258-259. On regulations in Poland more generally see: Magda Teter: "There should be no love between us and them." Social Life and the Bounds of Jewish and Canon Law in Early Modern Poland, in: Adam Teller, Magda Teter, and Antony Polonsky (eds.): Social and Cultural Boundaries in Pre-Modern Poland. Oxford 2010, 249-270, esp. 264. 
were well aware of the boundaries of each community. We can assume that here, like in Italy and elsewhere in Europe, the wearing of a special sign had a largely symbolic function. Traveling without such a sign afforded travelers protection on their already dangerous travels. In daily life, when most inhabitants already knew who belonged to the local Jewish community, specific signs served not only to keep up communal borders but also to refer to these borders symbolically.

Christian and Jewish insistence on strict sartorial boundaries or stigmatizing markers of difference shows that distinguishability was important to authorities of both religions. However, this does not mean that contemporaries were always able to tell Jews apart, as a polemical letter from the early sixteenth century suggests. At the beginning of the sixteenth century a dispute began between Johannes Pfefferkorn, a converted Jew from Cologne, and the famous humanist Johannes Reuchlin. Following Pfefferkorn's attempts to convince the Emperor Maximilian I to confiscate all Jewish books with allegedly anti-Christian content, including the Talmud, a set of anonymous satirical letters was published in 1515, followed by a second extended edition in 1517. These Letters of Obscure Men (Epistolae Obscurorum Virorum) were mostly a humanist defense of Reuchlin, who had turned against Pfefferkorn, as well as an attack on scholastic theology and on Pfefferkorn as a Jewish convert. ${ }^{8}$ In the second letter of the collection, a certain master Johannes Pellifex writes to the master Ortivinus Gratius and relates an episode that he had recently experienced in Frankfurt. He had gone to the Frankfurt fair, where he had walked together with a local student toward the market square. They came across two men, whose outward appearance was rather respectable. Both men wore black robes and large pointed hoods. The author, Pellifex, thus believed them to be two magistri nostri - theologians - and honored them by lifting his hat. The student was shocked and told Pellifex that these two men were clearly Jews, who obviously should not be greeted this way. Pellifex immediately regretted his action but defended himself by excusing his faux pas by his ignorance, as he had indeed taken them for two scholars. The remainder of the letter discusses the issue, remarking that Jews were actually always to wear a yellow ring on their gowns, and complaining about the fact that

8 On the debate and the Letters of Obscure Men see: Thomas Bartoldus: Humanismus und Talmudstreit. Pfefferkorn, Reuchlin und die "Dunkelmännerbriefe" (1515/17), in: Arne Domrös, Thomas Bartoldus, and Julian Voloj (eds.): Judentum und Antijudaismus in der deutschen Literatur im Mittelalter und an der Wende zur Neuzeit. Berlin 2002, 179-228. On the anti-Jewish tone of the Letters of Obscure Men see: Winfried Frey: Die "Epistolae obscurorum virorum" ein antijüdisches Pamphlet?, in: Renate Heuer (ed.): Probleme deutsch-jüdischer Identität. Bad Soden 1986, 147-172. 
the burghers of Frankfurt allowed the local Jews to walk around like scholars. ${ }^{9}$ Although this imaginary letter emerged from a polemic, it offers hints that in sixteenth-century Frankfurt Jews did not necessarily wear clothes that made them immediately recognizable on the street. Nevertheless, the local student was well aware that they were Jews, though he claims that he saw the yellow ring attached to their clothes.

About 200 years later, Johann Jacob Schudt (1664-1772), the well-known "ethnographer" of the Jews of Frankfurt, took up this story from the Letters of Obscure Men in his Jewish Curiosities (Jüdische Merkwürdigkeiten), published in 1714. ${ }^{10}$ Schudt, who showed considerable interest in Jewish daily life - though not without serious discontent with his Jewish neighbors - recounts the encounter from the Epistolae Obscurorum Virorum but notes that actually it was no longer necessary for Jews to wear yellow signs on their dress. ${ }^{11}$ He informs his readers, rather, that "the Jews wear black coats, black hats, generally clothes of dark color and around the neck a collar made from linen; the older and most distinguished ones also a round white linen ruff with many pleads and tucks, which, in addition to the beret, have their origin in the former Spanish costume". ${ }^{12}$ Thus, Schudt describes here the adoption of a specific costume that was probably most common in sixteenth- and seventeenth-century Spain. The linen ruff, especially when it came "with many pleads and tucks", was its most characteristic part. According to Schudt, Jews had adopted this costume and retained it when it became otherwise unfashionable. Despite Schudt's repeatedly antiJewish tone, one may assume that the changes he describes in Jewish dress are nevertheless reliable. Thus, by the early eighteenth century, Jews were most likely recognizable by their dress, at least in Frankfurt.

A similar phenomenon can be observed in the attire of Polish Jews, though we have few sources that can confirm what Jews wore before the second half of the eighteenth century. It seems that they mostly followed the style of the lower

9 Karl Riha (ed.): Dunkelmännerbriefe. Epistolae obscurorum virorum an Magister Ortuin Gratius aus Deventer. Frankfurt am Main 1991, 13-15.

10 On Schudt and his work see: Yaacov Deutsch: Jüdische Merckwürdigkeiten. Ethnography in Early Modern Frankfurt, in: Fritz Backhaus et al. (eds.): The Frankfurt Judengasse. Jewish Life in an Early Modern German City. Frankfurt am Main 2010, 73-84.

11 Officially, stigmatory signs were often abolished in the eighteenth century; in Frankfurt am Main in 1728, in the Habsburg Empire only in 1765. This, however, does not mean that Jews indeed wore those discriminatory signs until their annulment.

12 Johann Jakob Schudt: Jüdische Merckwürdigkeiten vorstelende was sich Curieuses und denckwürdiges in den neuen Zeiten bey einigen Jahrhunderten mit denen in alle IV Teile der Welt, sonderlich durch Teutschland, zerstreuten Juden zugetragen, Sammt einer vollständigen Franckfurter Juden-Chronik. Frankfurt am Main 1717, part 2, book VI, chapter 14, 247-248. 
nobility, including such typical items as the zupan, a long coat worn visibly under the outer garment, the delja, a long overcoat with long arms, and a wide belt. ${ }^{13}$ Nevertheless, Jewish communal authorities had sought to maintain a sartorial difference between Jews and non-Jews, especially the szlachta, the Polish nobility.

\section{Practices of Difference among Early Modern Ashkenazim}

The desire for sartorial distinction between Jews and Christians might not be surprising; however, early modern Jews assigned meaning to dress as a marker of internal difference as well. In general, Ashkenazi Jews (at least north of the Alps) are considered a unit; if inner-Jewish differences are taken into account, Ashkenazim are usually distinguished primarily from Sephardim. The latter had become an important part of Western and, to some extent, Central European Jewish life during the seventeenth century, when they settled increasingly in commercial centers like Amsterdam, Hamburg, and, later, London. ${ }^{14}$ In all three cities they encountered Ashkenazi Jews, locals as well as refugees, who arrived during the war-ridden seventeenth century from various German territories and from Poland-Lithuania, having fled from the repercussions of either the Thirty Years' War or the Khmelnytsky Uprisings of 1648/49.

The relation between Ashkenazim and Sephardim often proved complicated. In both Amsterdam and Hamburg Sephardic Jews financially supported Ashkenazi refugees, though they mostly attempted to remove the Jewish poor from the city and to send them elsewhere. Though Ashkenazim and Sephardim did business together, they maintained separate communities and did not intermarry. Often Sephardic Jews were not only wealthier than their Ashkenazi brethren but also thought of themselves as superior in a vague cultural sense.

13 Tamar Somogyi: Die Schejnen und die Prosten. Untersuchungen zum Schönheitsideal der Ostjuden in Bezug auf Körper und Kleidung unter besonderer Berücksichtigung des Chassidismus. Berlin 1982, 159-163. For a discussion of early modern noble dress in Poland see the contribution by Beata Biedrońska-Słota and Maria Molanda in this volume.

14 On Amsterdam see: Yosef Kaplan: Amsterdam and Ashkenazic Migration in the Seventeenth Century, in: Studia Rosenthaliana 23:2 (1989), 22-44; Daniel Swetschinski: Reluctant Cosmopolitans. The Portuguese Jews of Seventeenth-Century Amsterdam. London 2000. On Hamburg see: Jutta Braden: Hamburger Judenpolitik im Zeitalter lutherischer Orthodoxie: 1590-1710. Hamburg 2001. 
This included the Jews' outward appearance, as Menasseh ben Israel from Amsterdam noted in his famous address to Oliver Cromwell for the readmission of the Jews to England in 1655. While he argued for the Jews' economic usefulness and political harmlessness, ${ }^{15}$ he also blatantly displayed a condescending attitude toward northern European Ashkenazim. Concerning their appearance he remarks that "especially at Prague, Vienna and Franckfurt [sic] [they are] very much favoured by the most mild and most gracious Emperours, but despised of the people, being a Nation not very finely garnished by reasons of their vile clothing". ${ }^{16}$ Despite being esthetically unpleasant, these Ashkenazim had close ties to imperial power, and thus, Menasseh ben Israel argued, why should the much more pleasant and civilized Sephardim not be allowed to resettle in England.

Though the term Ashkenazim referred to Jews who descended from medieval Jewish inhabitants of the Rhineland and came to include Jews from northern France, England, northern Italy, Bohemia, Moravia, and eventually the Polish-Lithuanian Commonwealth, noticeable differences existed between different groups of Ashkenazim since the seventeenth century at the latest. Jews from early modern Poland and German-speaking lands could be distinguished for example by liturgy and customs (minhag). ${ }^{17}$ These differences were not only expressed on an intellectual level and in rabbinical writings, but also in folk literature, in which we find mention of apparent differences between Polish and German Jews in matters of everyday life such as food and dress.

Around 1675, a satirical Yiddish poem by an anonymous author was printed in Prague. Entitled "Di beshraybung fun ashkenaz un polak" (A description of Ashkenaz and Polak), the title already set a clear distinction between two Jewish entities: those Jews from the German-speaking lands and those from Poland. Eventually, the poem complicates things further as it introduces Jews from Prague as distinct from the other two groups. It probably is "the most famous

15 Lucien Wolf (ed.): Menasseh ben Israel's Mission to Oliver Cromwell. Being a Reprint of the Pamphlets Published by Mensasseh ben Israel to Promote the Re-admission of the Jews to England, 1649-1656. London 1901. See also: Jonathan Karp: The Politics of Jewish Commerce. Economic Thought and Emancipation in Europe, 1638-1848. Cambridge 2008, 32-37.

16 Wolf, Menasseh ben Israel's Mission, 86.

17 See for example: Adam Teller: Jewish Literary Responses to the Events of 1648-1649 and the Creation of a Polish-Jewish Consciousness, in: Benjamin Nathans and Gabriella Safran (eds.): Culture Front. Representing Jews in Eastern Europe. Philadelphia 2008, 17-45; Joseph Davis: The Reception of the "Shulhan 'Arukh" and the Formation of Ashkenazic Jewish Identity, in: AJS Review 26 (2002), 251-276; Elkhanan Reiner: The Rise of an Urban Community. Some Insights on the Transition from the Medieval Ashkenazi to the 16th Century Jewish Community in Poland, in: Kwartalnik Historii Żydów 207 (2003), 363-372. 
and elaborate literary example for the expression of a pre-Haskalah [Jewish enlightenment] inner Ashkenazic bias". 18 The poem describes a Polish Jew wandering through German lands, probably one of the refugees of 1648/49 or from the later Northern War (1655-1660) between Sweden and the Polish-Lithuanian Commonwealth. The anonymous author ${ }^{19}$ mentions several shortcomings of Polish Jews, including infidelity in marriage, superficial religiosity, fraudulence, and theft, but also complains about the lack of hospitality in Jewish communities in German lands. He mentions explicitly Frankfurt, Worms, Fürth, Hamburg, Halberstadt, Friedberg and many others. According to the author, Jews in these communities mistrusted Polish Jews and took them for thieves; they hardly let them into their houses and tried to send them away with little food and as quickly as possible. The author also mocks Jews of the German lands for their outward appearance, for wearing only one coat and one hat on weekdays and Shabbat and for wearing shoes that were studded with nails. Moreover, their beard was trimmed short, leaving only a kamats, which refers either to some kind of goatee or to a mustache with a small goatee in the form of the Hebrew vowel point kamats, which also was called a kamats-berdele in Yiddish. ${ }^{20}$ In contrast, the author describes the dress of the Polak, consisting of a shupits (a long winter coat with fur; Polish żupan or żupica) and a shoibn (a long overcoat with fur; Polish szuba) $)^{21}$ with its wide sleeves, as making for a more dignified appearance, even though the Ashkenaz pokes fun at him.

18 Diana Matut: What Happened in Hamburg ... A Yiddish Document about Polish Jews in Germany during the Early Modern Period, in: Marion Aptroot et al. (eds.): Leket. Jiddistik heute/ Yiddisch Studies Today. Düsseldorf 2012, 321-355, quotation 331. The poem has been published by Max Weinreich: Tsvei yidishe shpotlider oif yidn, in: Filologishe shriftn 3 (1929), c. 537-554. On the satirical poem in general see: Ewa Geller: Aschkenas und Polak. Ein Jahrhunderte währender Antagonismus, exemplarisch dargestellt an einem jiddischen Streitlied aus dem 17. Jahrhundert, in: Nathanael Riemer (ed.): Jewish Lifeworlds and Jewish Thought. Festschrift Presented to Karl E. Grözinger on the Occasion of his 70th Birthday. Wiesbaden 2012, 357-368.

19 Max Weinreich and Maks Erik assumed that the author was probably a Polish Jew, who had traveled through German lands, while Ewa Geller argues that the language has the character of Western Yiddish and thus, the author might instead be a Jew from German lands. Geller, Aschkenas und Polak, 359, note 313.

20 Weinreich, Tsvei yidishe shpotlider oif yidn, c. 543.

21 The German term Schaube for an overcoat probably refers to a similar garment, used in sixteenth-century German lands, though it is difficult to say to what extent it differed from a szuba. See: Jutta Zander-Seidel: Textiler Hausrat. Kleidung und Haustextilien in Nürnberg von 1500-1650. Berlin 1990, 55. See also: Schaube, in: J.G. Krünitz (ed.): Oekonomische Encyklopädie, vol. 140. Berlin 1825, 545. URL: http://www.kruenitz1.uni-trier.de/background/en tries_vol14Ob.htm (22 Dec. 2018). 
Though the differences in dress and outward appearance played only a minor role in this satirical poem and were not the most significant distinction the author described, the wording shows clear differences in dress that were fully developed by the second half of the seventeenth century. Thus, we see that geographic origin and the corresponding sartorial practices played a central role as a marker of inner-Jewish difference already in the seventeenth century. The image of the pre-Enlightenment Jew in "oriental” garb, including caftan and beard, versus the modern and enlightened Jew dressed in WestEuropean fashion seems to be an invention of the Haskalah that sought to level out the differences among early modern Jews. ${ }^{22}$

\section{Internal Restrictions: Jewish Sumptuary Laws}

Jewish communities throughout Central and East Central Europe were concerned with their members' outward appearance throughout the early modern period. New ordinances (takkanot) that were more detailed than those of the thirteenth century emerged from the late sixteenth century onward. They were based on the older principles of a general distinguishability of Jews from nonJews, the prohibition against mixing wool and linen, and the prohibition against wearing one's hair like non-Jews or to shaving one's beard completely, as well as a warning against excessive luxury and indecent female dress. These warnings and prohibitions were repeated in the early modern halakhic literature (Jewish legal texts), most prominently the Shulchan Aruch (The Set Table), first printed in 1565. In addition, the genre of communal ordinances began to develop. While earlier ordinances existed in fifteenth-century Spain and Italy, ${ }^{23}$ the earliest known sumptuary laws in Central and East Central Europe are those of the Jewish community of Cracow from $1595 .^{24}$ These first sumptuary laws of a Jewish community in Poland are mostly concerned with the usage of luxury

22 For this phenomenon of the Haskalah period see: Kathrin Wittler: Orientalist Body Politics. Intermedia Encounters between German and Polish Jews around 1800, in: Central Europe 17 (2019), [forthcoming].

23 Rubens, A History of Jewish Costume, 184-185. In general see: Louis Finkelstein: Jewish Self-Government in the Middle Ages. New York 1924. On Italy: Diana Owen Hughes: Distinguishing Signs. Ear-Rings, Jews and Franciscan Rhetoric in the Italian Renaissance City, in: Past \& Present 112:1 (1986), 3-59.

24 The communal ordinances are printed in: Majer Bałaban: Die Krakauer JudengemeindeOrdnung von 1595 und ihre Nachträge, in: Jahrbuch der Jüdisch-Literarischen Gesellschaft 10 (1912), 296-360, 11 (1916) 88-114. On the ordinances see: Edward Fram: Hagbalat motarot 
items, certain furs, stones, and gold and silver threads. The ordinances do not mention any garments in particular, but rather a variety of embellishments that Jews were to refrain from, at least if they did not belong to the small group of wealthy community members paying the highest taxes. Additional distinctions were made between items allowed within the Jewish quarter but prohibited outside of it, and items that were only acceptable on certain holidays and feasts.

The high degree of internal autonomy of the Jewish communities in the Polish-Lithuanian Commonwealth led to the emergence of transregional Jewish governing bodies. On the most central level these were the Council of the Four Lands (Va'ad arba aratsot), representing Jews from Great Poland, Little Poland, Ruthenia, and Volhynia, which adapted more organized forms in the 1580s; and the Lithuanian Council (Va'ad medinat lita), which emerged in the first half of the seventeenth century. ${ }^{25}$ Already in 1607, the Council of the Four Lands explicitly prohibited the wearing of "clothes of non-Jews and prostitutes", even for the wealthiest. The ordinance does not specify what is meant by non-Jewish dress or by the dress of prostitutes, though one might assume that the latter refers to the dress of non-Jewish women in general, ridiculing them a "prostitutes", a rather common means of countering Christian dominance. ${ }^{26}$ The same prohibition was repeated in 1637 in the ordinances of the Lithuanian Council, including an explicit warning to tailors and other artisans to observe these regulations when producing or (much more likely) altering used clothing. At this point a concrete garment is mentioned. The regulations prohibit men from wearing a żupan made of atlas and damask, with the exception of the very wealthy who paid over 4,000 ducats in community taxes annually. ${ }^{27}$ This regulation, however, confirms that Jews indeed wore the żupan, which was usually tied together with a wide belt. Thus, Jews participated sartorially in early modern Polish society and adapted themselves toward the fashion of the Polish nobility in particular. Though the

be-kehilah ha-yehudit be-Krakov be-shalhe ha-me'ah ha-16 uve-re'shit ha-me'ah ha-17, in: Gal-Ed 18 (2002), 11-23.

25 The takkanot of the Council of the Four Lands did not survive, but have been reconstructed from other sources and published first in 1952 by Israel Halperin. Israel Halperin and Israel Bartal (eds.): Pinkas va'ad arba' aratsot: likute takkanot, ketavim u-reshumot, 2nd ed. Jerusalem 1989. The takkanot of the Lithuanian Council were published by Simon Dubnov (ed.): Pinkas medinah o pinkas va'ad ha-kehilot ha-rashiyot bi-medinat Lita. Berlin 1928. On Jewish autonomy in Poland see: Adam Teller: Telling the Difference. Some Comparative Perspectives on the Jews' Legal Status in the Polish-Lithuanian Commonwealth and the Holy Roman Empire, in: Polin 22 (2009), 109-141.

26 Maria Diemling: Navigating Christian Space. Jews and Christian Images in Early Modern German Lands, in: Jewish Culture and History 12 (2012), 397-410.

27 Halperin and Bartal, Pinkas va'ad arba' aratsot, 17-18; Dubnov, Pinkas medinah, 68, no. 313. 
żupan was worn by nobility, it was also worn by Jews and some burghers as well; the finer distinctions were made through fabrics and embellishments. Poorer noblemen mostly wore a white linen or woolen żupan, whereas wealthier members of the nobility used brocade, silk, or velvet, embellished with gilt buttons and tied with expensive silk sashes (instead of simple woolen ones). In the sixteenth and seventeenth centuries even some better-off peasants owned a żupan and patterned belts, though these were probably not worn daily but as festive garments. ${ }^{28}$ Thus, one might argue that the different estates or status groups (in the case of the Jews) competed against each other less in the specific garments worn and more in the richness and value of the fabrics and accessories (Figure 1).

As members of the Polish nobility increasingly adapted to a more Western European style of clothing, incorporating and adapting new fashionable cuts and accessories, it seems that Jews in Poland rather retained traditional garments, not unlike the developments in German lands to which we will return later. The last sumptuary laws regarding dress appeared in the minute book (pinkas) of the Lithuanian Council in 1761, three years before this central Jewish governing body was abolished, along with its Polish counterpart, the Council of the Four Lands, by the last Polish king, Stanisław August Poniatowski. The ordinances of 1761 did not prohibit the wearing of non-Jewish dress in particular, although they did state that it was forbidden to make new dresses from used Christian ones. On the other hand, the ordinances permitted Jews to buy used clothes even when made from silk or embroidered with gold and silver. ${ }^{29}$ The ordinances, however, explicitly mentioned the caftan as a permitted garment, along with vests (vestin) and stomachers (zalishkes) to be worn during the week and Shabbat and at any place, including markets and streets, that is, spaces that were conceived as non-Jewish. It was likewise permitted to make these garments anew or to repair them. The caftan, a long buttoned coat-like garment, is thus mentioned as a garment of everyday use. ${ }^{30}$

28 Maria Bogucka: The Lost World of the "Sarmatians". Custom as the Regulator of Polish Social Life in Early Modern Times. Warsaw 1996, 103, 105-106, 108-109.

29 Dubnov, Pinkas medinah, 272, no. 1024-1026. The prohibition might be related to the traditional fears of reworking stolen goods. On Jews as fences see: Shaul Stampfer: Jews as Fences in Early Modern Poland and Beyond. Function, Ideology, Almost Philanthropy and Almost Diplomacy in a Complex Society, in: Jewish Culture and History (Transformations and Intersections of Shtadlanut and Tzedakah in the Early Modern Period) 19 (2018), 23-38.

30 Dubnov, Pinkas medinah, 272, no. 1025. See also: Somogyi, Die Schejnen und die Prosten, 166, 191-192. 


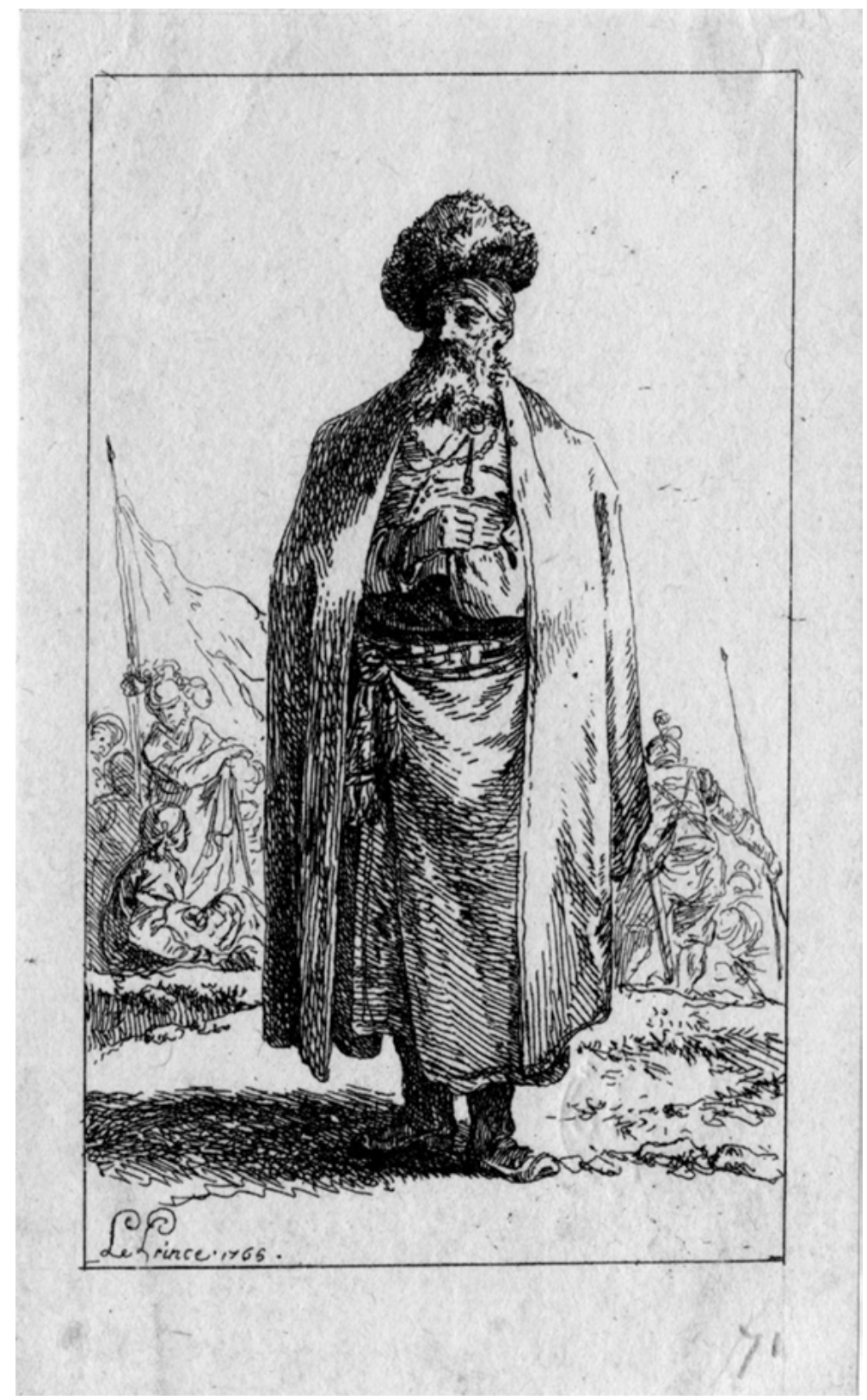

Figure 1: Juif Polonois (Jewish Pole), 1765, Etching, in: Jean Baptiste Le Prince: Habillements de diverses nations, The British Museum Online Collection, Creative Commons: CC BY-NC-SA 4.0. 
Communal sumptuary laws from the towns of Dubno, Tiktin (Tykocin), and Nieśwież from the same time period likewise did not stipulate any concrete prohibition against wearing non-Jewish dress. Evidently it was clear that Jewish attire differed in style and cut. The ordinances from Nieśwież, an important Jewish community in eighteenth-century Poland-Lithuania, focused rather on the embellishment of garments. Visible outer garments for women like the tshuhai, an overcoat, the fartuch, an apron, and bonnets were not to be interwoven or embroidered with silver and gold. The same embellishment, however, was permissible on the standard pieces of dress - caftan, vest, and stomachers (zalishkes) worn as layers under an outer gown. Here, gold and silver embroideries were allowed as long as they were displayed only at home, but worn in reverse on the street and on the way to synagogue. ${ }^{31}$ The embroidery was to remain invisible to the Christian eye. Thus the prohibition was concerned with the display of luxury and not with the distinguishability of Jewish men and women.

\section{Dressed in "Jewish Attire"}

A rare series of inventories from the small town of Biała Podlaska, near Warsaw, seems to confirm this impression. ${ }^{32}$ Inventories are not simply "snapshots of reality"; they are created by individuals with specific intentions in mind. However, as "representations of the domestic" they can provide some glimpse into the ownership of particular garments. ${ }^{33}$ Following the devastation of the noble town in 1764, which belonged to the Radziwiłl family, about 300 Jewish and 42 Christian burghers of the town submitted lists with damages to the Radziwiłłs. From the overall sum of nearly half a million zloty only about 10,000 zloty were claimed by the few Christian inhabitants, most of them

31 Anna Michałowska: Gminy żydowskie w dawnej rzeczypospolitej. Wybór tekstów źródołwych. Warsaw 2003, 127-128. On the garments see also: Somogyi, Die Schejnen und die Prosten, 199-204.

32 The inventories are found in: Akta tyczące się szkoć przez Karola Stanisława Kcia Radziwiłła i Jego poddanych przez rabunek r. 1764 poniefionych, Archiwum Warszawskie Radziwiłłów, XXIII [further AR XXIII], t. 7, pl. 2; t. 8, pl. 1 (AGAD Warsaw). On Biała Podlaska see: Andrzej W. Rachuba: Biała pod rządami Radziwiłłow w latach 1568-1813, in: Tadeusz Wasilewski and Tadeusz Krawczak (eds.): Z nieznanej przeszłości Białej i Podlasia. Biała Podlaska 1990, 37-65.

33 On the critical evaluation of inventories as a source see: Giorgio Riello: "Things Seen and Unseen." The Material Culture of Early Modern Inventories and Their Representation of Domestic Interiors, in: Paula Findlen (ed.): Early Modern Things. Objects and Their Histories, 1500-1800. London 2013, 125-150, esp. 127. 
illiterate. Garments were not always mentioned in detail and, especially in the case of Jewish merchants, one must carefully distinguish between private pieces of dress and merchandise; none of the Christians, however, owned a żupan or a caftan. Most often the inventories mention a shirt (koszula), a shawl (chusteczka), and a bonnet (czapka), sometimes an apron, a hat, a scarf, and a pair of pants. ${ }^{34}$ Most of the Jewish inventories, however, do mention a single żupan, and more rarely a kontusz and/or a caftan. If these are single items and not mentioned in conjunction with other textiles that might have been part of merchandise, one may assume that they were garments owned in addition to the ones worn when the damage to the town occurred.

Moreover, a cursory look at wanted notices in the Polish newspaper Gazeta Warszawska from the last quarter of the eighteenth century confirms that the inhabitants of the city, Jewish and Christian, must have had a very concrete idea of different types of dress. Between 1776 and 1788, and again between 1796 and 1806, 27 Jews were described in wanted notices, often after having fled from a first arrest or prison. When, for example, the authorities searched for a certain Faibus Jossiewicz, who had escaped after his arrest, he was described as follows:

He is about 24 years old, of small stature, has red hair, a suchlike beard, a haggard and pale face, and speaks only Jewish-German [i.e. Yiddish] and Polish. At the time of his escape he wore Polish Jewish clothing and there was nothing exceptional beyond that, except that he was fast in his movements and spoke rather quickly. ${ }^{35}$

Most of the Jews' dress was similarly designated as Jewish in some way. A caftan is only mentioned once, the zupan eight times without any further definition and twice as a Jewish garment (żupan $\dot{z} y d o w s k i e)$. Nine times we find the attire described as Jewish; apparently the reader knew what was meant when he/she read "in a Jewish garment" ( $w$ suknia żydowska), "Polish-Jewish dress" (polska-żydowska suknia/ w stroiu polski$\dot{z} y$ dowski), or simply "in Jewish manner" (po żydowsku). In addition to the aforementioned $\dot{z}$ upan, the following garments were also described as Jewish: a black coat (płaszcz czarny $\dot{z} y$ dowskie), a vest (żydowska kamizielka), and two different headcovers (żydowska czapka, kapturek $\dot{z}$ ydowski). Only in seven cases is there no typical garment or additional descriptor "Jewish" to be found, while two Jews were dressed in different

34 AR XXIII, t. 7, pl. 2, 1-2, 226-310 (AGAD Warsaw).

35 Gazeta Warszawska, October 20, 1797, no. 84, supplement. This wanted-ad was published in German as Warsaw was under Prussian rule at the time. 
styles: one in a long Polish garment (suknia dtuga Polska) and a certain Marek Moyźesz in French manner (ubrany po Francusku). ${ }^{36}$

Thus, those who described these Jews on the run, and presumably also those who read the wanted notices in the Gazeta Warszawska, had a relatively clear understanding of what was meant by Jewish dress or attire; what a Jewish hat or a Jewish vest looked like; and that a żupan, for example, was a piece of clothing often worn by Jews. In contrast, in German Jewish police lists with wanted notices from the first half of the eighteenth century onward, we do not find such general ascriptions, if we find descriptions of dress at all. ${ }^{37}$ Detailing clothes made little sense, according to the authors of these lists, because many of the alleged criminals and vagabonds changed their clothing regularly. But even when dress was mentioned and described, generic terms like Jewish or German-Jewish dress are absent. This, however, does not mean that a specific Jewish attire did not develop in German-speaking lands, at least in parts of Jewish society.

\section{From Spanish Dress to Honorary Garments}

The attitudes toward Jewish dress and, certainly, the varieties of garments worn by early modern Jews, were even more diverse in German-speaking lands. Though depicted as a rather homogeneous group in the above-mentioned polemical poem mocking their habits of dress, Jewish communities were diverse in size, location, and social composition, and thus also in access to clothes, fabrics, and luxury items. The expulsions of the late medieval period had fundamentally changed the composition of Jewish communities in the German lands. The urban communities in the Rhineland and elsewhere had mostly vanished. Jews in Frankfurt am Main and Worms lived in separate parts of their respective cities;

36 Gazeta Warszawska, December 4, 1776, no. 97, supplement; May 9, 1781, no. 37, supplement; July 20, 1785, no. 85, supplement; August 3, 1785, no. 62, supplement; February 16, 1788, no. 14, supplement; April 19, 1796, no. 32, supplement; July 14, 1797, no. 56, supplement; October 20, 1797, no. 83, supplement; August, 31, 1798, no. 70, supplement; Ocotber 25, 1799, no. 86, supplement; December 30, 1800, no. 104, supplement; September 22, 1801, no. 76, supplement; December 15, 1801, no. 100, supplement; June 8, 1802, no. 46, supplement; November 8, 1803, no. 89, supplement; May 10, 1805, no. 38, supplement; November 4, 1806, no. 88, supplement.

37 See for example: Acten-mäßige Designation derr von einer diebischen Juden-Bande verübten Kirchen-Raubereyen und gewaltsamen mörderischen Einbrüche, samt Angefügter Beschreibung derer meisten Jüdischen Erz-Diebe [.. .], 2nd ed. Coburg 1735; Acta betr. die in Hessen Schaumburgschen entdeckte Räuber und Diebesbande (1802-1804), HA I, Rep. 21, no. 206c 1, Fasz. 37 (Geheimes Preußisches Staatsarchiv Berlin); Criminalia 6.643, Steckbrief des Hochstifts Münster (Institut für Stadtgeschichte, Frankfurt am Main). 
the Jews expelled from Nuremberg in 1499 resettled in Fürth, just outside of Nuremberg. Many small communities spread across villages and small towns, especially in Franconia. Other communities, like Halberstadt, were reestablished after the settlement of individual families of Court Jews, who built communities around family members and servants. Brandenburg-Prussia, marked by the devastations of the Thirty Years' War, readmitted Jews to its territories only in the late seventeenth century. ${ }^{38}$

No strong trans-regional representation of the Jewish communities developed in the German-speaking lands comparable to the Council of the Four Lands or the Lithuanian Council. Sumptuary laws were thus stipulated by local communities only, with the exception of the more general ordinances (takkanot) from seventeenth- and early eighteenth-century Moravia. Throughout the seventeenth and eighteenth centuries, relatively short regulations can be found in the Habsburg lands (Kremsier, Nikolsburg, and Prague) and in Friedberg and Halberstadt; more extensive laws are found in the three communities of Hamburg, Altona, Wandsbek, and in Frankfurt am Main, Fürth, and French Metz; while in Prussia, for example, no such ordinances are known from any relatively large Jewish community. ${ }^{39}$ The shorter of these sumptuary laws usually prohibited various expensive fabrics, gold and silver threads, and similar luxury goods in general, often pertaining in particular to women. Some distinguished between Jewish and Christian space and prohibited some garments or

38 On the development of Jewish communities in Germany in general see: Jonathan Israel: European Jewry in the Age of Mercantilism, 1550-1750, 3rd ed. London 1998; Mordechai Breuer and Michael Graetz: Tradition and Enlightenment 1600-1780. New York 1996; Michael A. Meyer (ed.): German-Jewish History in Modern Times, vol. 1. New York 1996, 70-78, 82-121.

39 Israel Halperin: Takkanot medinat Mehrin (5410-5508). Jerusalem 1952, 99-100, 160, 183-184, 198-200; Adolf Frankl-Grün: Die Gemeindeverfassung von Kremsier, in: Monatsschrift für die Geschichte und Wissenschaft des Judentums 40:4-6 (1896), 180-184, 209-219, 255-261; Abraham Naftali Zvi Roth (ed.): Sefer takkanot Nikolsburg. Jerusalem 1961; Yikutiel Kamelhar: Sefer mofat ha-dor. Toldot rabbenu Yicheskiel Halevi Landau z"l. Piotrków 1934; Stefan Litt: Protokollbuch und Statuten der Jüdischen Gemeinde Friedberg (16.-18. Jahrhundert). Friedberg 2003. For Halberstadt, Fürth (1770) and Metz see: Stefan Litt (ed.): Jüdische Gemeindestatuten aus dem aschkenasischen Kulturraum 1650-1850. Göttingen 2014, 107-131, 132-273, 353-395; Andreas Würfel: Historische Nachricht von der Judengemeinde in dem Hofmarkt Fürth Unterhalb Nürnberg 1. Die Beschreibung v. d. Juden Ansitz in d. Hofmark Fürth ... ; 2. Das Tekunnos Büchlein d. Fürther Juden. Frankfurt am Main 1754; Johann Jakob Schudt: Neue Franckfurter Jüdische Kleider-Ordnung [...]. Frankfurt am Main 1716; Heinz Mosche Graupe (ed.): Die Statuten der drei Gemeinden Altona, Hamburg und Wandsbek. Quellen zur jüdischen Gemeindeorganisation im 17. und 18. Jahrhundert. Hamburg 1973; Max Grunwald: Luxusverbot der Dreigemeinden (Hamburg - Altona - Wandsbek) aus dem Jahre 1715, in: Jahrbuch für jüdische Volkskunde 25 (1923), 227-234. 
embellishments only outside of the Jewish home, street, or synagogue. The more extensive sumptuary laws likewise drew a number of social distinctions, according to status within the community (e.g. servants) or the amount of taxes a community member paid. Unsurprisingly, the most extensive sumptuary laws were from Hamburg/Altona/Wansbek and Metz, wealthy and well-connected Jewish communities.

For my purpose here, however, the sumptuary laws from Frankfurt am Main and from Fürth are the most interesting, as they seem to support the emergence of a particular Jewish attire, specific to at least some German Jews, in the eighteenth century at the latest. In both cases, one might argue that certain garments held honorary value and constituted part of a local Jewish identity. This feeling of belonging was based on membership in larger urban Jewish communities and on the holding of residential rights. This attitude was reflected in the sumptuary laws of both communities from the first decades of the eighteenth century. In both Frankfurt and Fürth the Shabbes cloak was of symbolic importance, as only full members of the community who received the so-called Stättigkeit (the right to settle permanently in the city) were allowed to wear it. The Frankfurt ordinances, which were promulgated after a devastating fire in the Jewish ghetto in 1711, were handed down only in an edition, including a translation into German, by Johann Jacob Schudt, the "ethnographer" of the Frankfurt Jewish community. ${ }^{40}$ In the wake of the destruction of many houses in the Frankfurt Jewish street, the sumptuary laws stipulated that the Shabbes cloak should not be made from silk and that only young men who already owned such a cloak were allowed to wear it. Schudt commented that the Jews had a specific cloak for synagogue with a hole for the arms, i.e. without sleeves, which foreign Jews were not allowed to wear. Local Jews likewise were not allowed to wear it immediately after their wedding, but only once they officially received their Stättigkeit. ${ }^{41}$ As mentioned earlier, Schudt also described the dress of Frankfurt Jewry as a typically Jewish dress with the black Shabbes cloak and a rather elaborate ruff.

Even though these were garments worn especially on Shabbat and on holidays, both remained the object of repeated dispute throughout the eighteenth century within the Jewish community in Frankfurt and between the elders and the magistrate. Both garments, cloak and ruff, had honorary meaning, and in

40 On Schudt, whose writings contain numerous anti-Jewish statements, see: Maria Diemling: The Ethnographer and the Jewish Body. Johann Jacob Schudt on the Civilisation Process of the Jews of Frankfurt, in: Jewish Culture and History 10 (2008), 95-110; Deutsch, Jüdische Merckwürdigkeiten. Ethnography in Early Modern Frankfurt, 73-84.

41 Schudt, Neue Franckfurter Jüdische Kleider-Ordnung, 48, § 35. 
1754 the elders of the Frankfurt Jewish community stipulated, in a set of regulations consisting of 126 paragraphs concerning different areas of Jewish life, that Jewish bankrupts were not only banned from all honorary posts and from reading the Torah in synagogue, but were also prohibited from wearing a white collar or ruff and the Shabbes cloak. ${ }^{42}$ Thus, both were honorary garments linked closely to one's position in the community and were invested with pride.

The importance of the Shabbes cloak as a sign of belonging had not vanished even by the late eighteenth century. Repeatedly, individuals complained that while their fathers had residential rights in Frankfurt, they as their sons would not receive the same rights automatically and thus were banned from wearing the Shabbes cloak. The magistrate, however, was less interested in this question and more concerned with the right to trade, which was likewise linked to residential rights. The magistrate remarked that many cases like this had been taken to the courts, but insisted that only Jews who have received residential rights themselves - irrespective of their fathers' status - were allowed to wear the cloak. The magistrate did not recognize the symbolic importance of these garments. A report concerning the issue stated, "as far as I am aware the Shabbes cloak, the Shabbes cap (Schabbes Deckel) and ruff are only worn in the [Jewish] street on their Shabbes and holidays". ${ }^{43}$ Even in 1795 a certain Salomon Joseph Spiegel complained to the municipal authorities that the communal elders not only refused to grant residential rights to his future son-inlaw Moses Schweitzer, but also withheld the right to wear the Shabbes cloak and ruff. The latter garments became the symbol for residential rights during the dispute that continued for many years. ${ }^{44}$

In Fürth, the Shabbes cloak (Schul-Mantel) and the ruff fulfilled a similar function. The Protestant theologian Andreas Würfel, who published a history of the Jews in Fürth in 1754, remarked that the elders of the community held the right to grant and withdraw residential rights, which were likewise tied to the right to wear the Shabbes cloak and ruff on Shabbat. ${ }^{45}$ The sumptuary laws of the Fürth community from 1728, according to Würfel's translation, stipulated

42 Juden Akten 975, Reglement die hiesige Schutz Juden betr. 1754, 55 (Institut für Stadtgeschichte Frankfurt am Main). The regulations were penned following inner-communal conflict between two families. In this context, new sumptuary laws were also planned, but apparently never written or published. Isidor Kracauer: Geschichte der Juden in Frankfurt a. M., 1150-1824, vol. 2. Frankfurt am Main 1925, 205-211.

43 Juden Akten 458, no. 41 (Institut für Stadtgeschichte Frankfurt am Main).

44 Juden Akten 209 (Institut für Stadtgeschichte Frankfurt am Main).

45 Würfel, Historische Nachricht von der Judengemeinde in dem Hofmarkt Fürth, 5. Würfel's anti-Jewish tone is often harsher than that of Schudt. On the takkanot of Fürth see also: Litt, Jüdische Gemeindestatuten aus dem aschkenasischen Kulturraum, 133. 
that "one needs to be able to distinguish men by their costume and thus one needs to be able to distinguish those who study from other men and servants". Therefore all students local and foreign had to wear ruffs. Würfel added here that all Jews wore big ruffs on Shabbat, while during the week students wore a small ruff, and those honored with the title morenu (our teacher) were always permitted to wear a big ruff. ${ }^{46}$ Ruffs thus also functioned as a marker of internal difference within the Jewish community.

That typical Jewish Shabbat attire included the Shabbes cloak and a ruff is also confirmed by eighteenth-century engravings, many of which were engraved in Nuremberg, close to Fürth. The 1703 costume book Neu-eröffnete Welt-Galleria included an engraving of a "Frankfurt Jew and Jewess" produced by the Dutch engraver Caspar Luyken (1672-1708) and the Nuremberg engraver and publisher Christoph Weigel (1654-1725), who had worked together in Nuremberg since $1699 .{ }^{47}$ For the spectator, the couple was probably to be identified as Jewish by the collar, the hat, and the cloak (though probably not a Shabbes cloak) of the male figure and the ruff and the winged bonnet of the female figure (Figure 2). The two female garments were mentioned, for example, in a 1785 inventory of possessions brought into marriage. When Rebecca Baruchen, the daughter of the communal leader Liebmann Baer from Breslau, was about to marry the Court Jew David Baruch in Bayreuth, she brought with her over 20 dresses, countless jewelry, many pieces of white cloth, and laces, but also one bonnet with "wings" (Haube mit Flügeln) and a ruff (Halsfriess) that together were worth more than 100 ducats. $^{48}$ Though the richness of her clothes was exceptional, these items seemingly belonged to a well-off family's closet.

The Welt-Galleria, like other early modern costume books, was a means to depict ideal types and to confirm a certain imagined order of early modern society. ${ }^{49}$ Thus, in his introduction to the work, the Catholic Viennese preacher Abraham a Sancta Clara firmly pointed to the importance of dress as a marker of estate and origin and criticized the wearing of attire of other "nations". It is

46 Würfel, Historische Nachricht von der Judengemeinde in dem Hofmarkt Fürth, 151, § 110.

47 Abraham Sancta Clara, Christoph Weigel, and Caspar Luyken: Neu-eröffnete Welt-Galleria worinnen sehr curios und begnügt unter die Augen kommen allerley Aufzüg und Kleidungen unterschiedlicher Stande und Nationen. Nürnberg 1703, no 39. On the emergence of costume books see Ulrike Ilg: The Cultural Significance of Costume Books in Sixteenth-Century Europe, in: Catherine Richardson (ed.): Clothing Culture, 1350-1650. Aldershot 2004, 29-47. See also: Colding Smith: "Depicted with Extraordinary Skill”. Ottoman Dress in Sixteenth-Century German Printed Costume Books, in: Textile History 44 (2013), 25-50.

48 Adolf Eckstein: Geschichte der Juden im Markgrafentum Bayreuth. Bayreuth 1907, 124-128. 49 Ilg, The Cultural Significance of Costume Books in Sixteenth-Century Europe, 43. 


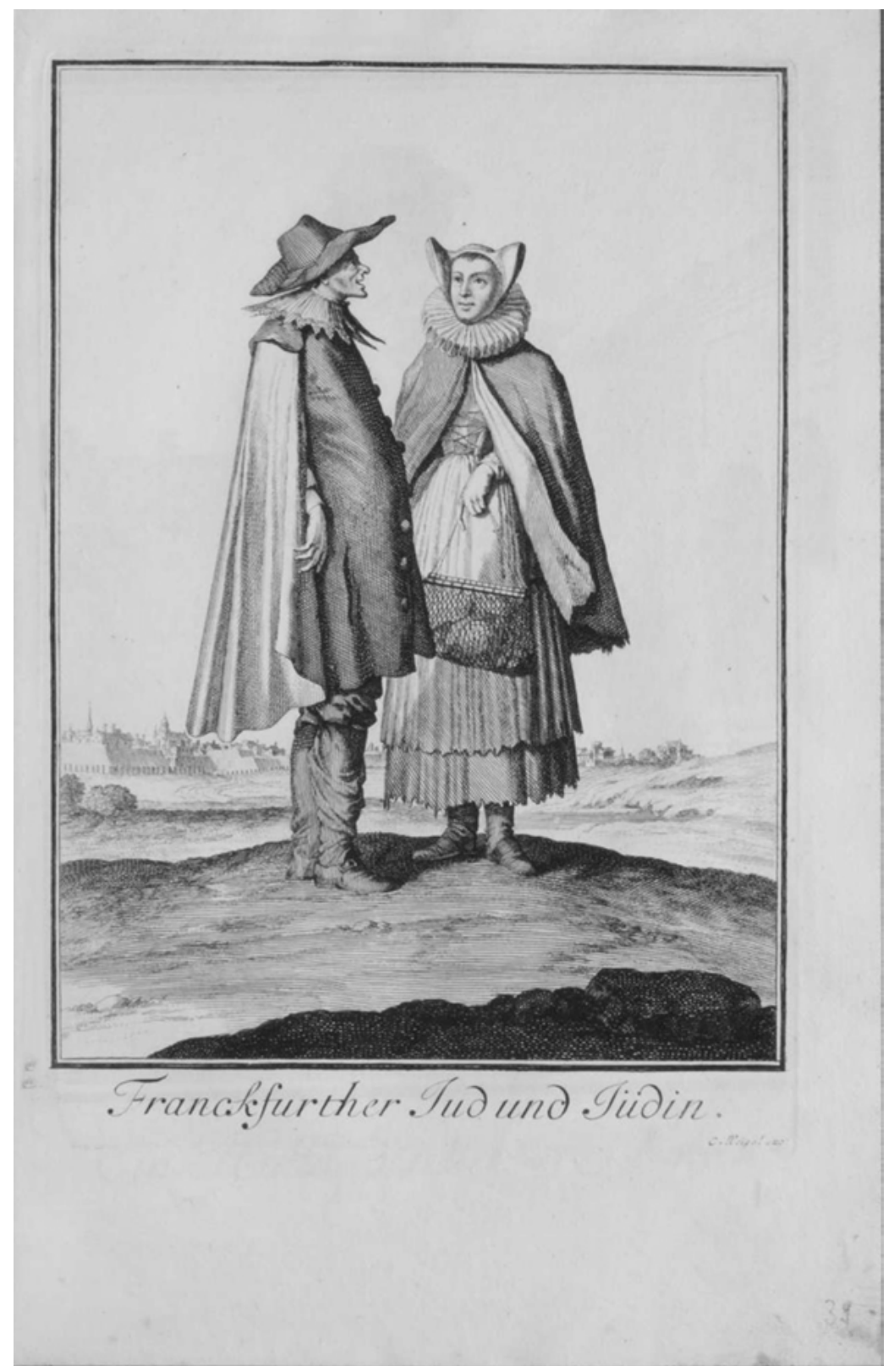

Figure 2: Frankfurter Jud und Jüdin, in: Abraham a Sancta Clara: Neu-eröffnete Welt-Galleria: Worinnen sehr curios und begnügt under die Augen kommen allerley Aufzüg und Kleidung unterschiedlicher Stände und Nationen [. . .]. Nürnberg 1703, Herzog August Bibliothek Wolfenbüttel @ HAB http://diglib.hab.de/drucke/wt-4f-93/start.htm?image $=00085$. 
therefore all the more interesting that the engraving of the Jewish couple was immediately preceded in the book by engravings of women and peasants from Regensburg and Nuremberg and was followed by a Dutch merchant and other Dutch figures but was not grouped together with the only other Jew in the volume, a Polish Jew (no. 71) who followed three other Polish figures: a nobleman, a hajduk (a foot soldier), and a peasant. Similar depictions of Fürth Jews can be found in the work of Johann Alexander Boener (1647-1720), a local engraver who produced a series of engravings of Nuremberg and Fürth, including the synagogue and the Jewish cemetery along with groups of Jews. In all of the engravings Jewish men and women were depicted with collars and ruffs and men with Shabbes cloaks. Although these garments were not worn daily, they marked the individuals as Jewish men and women (Figure 3).

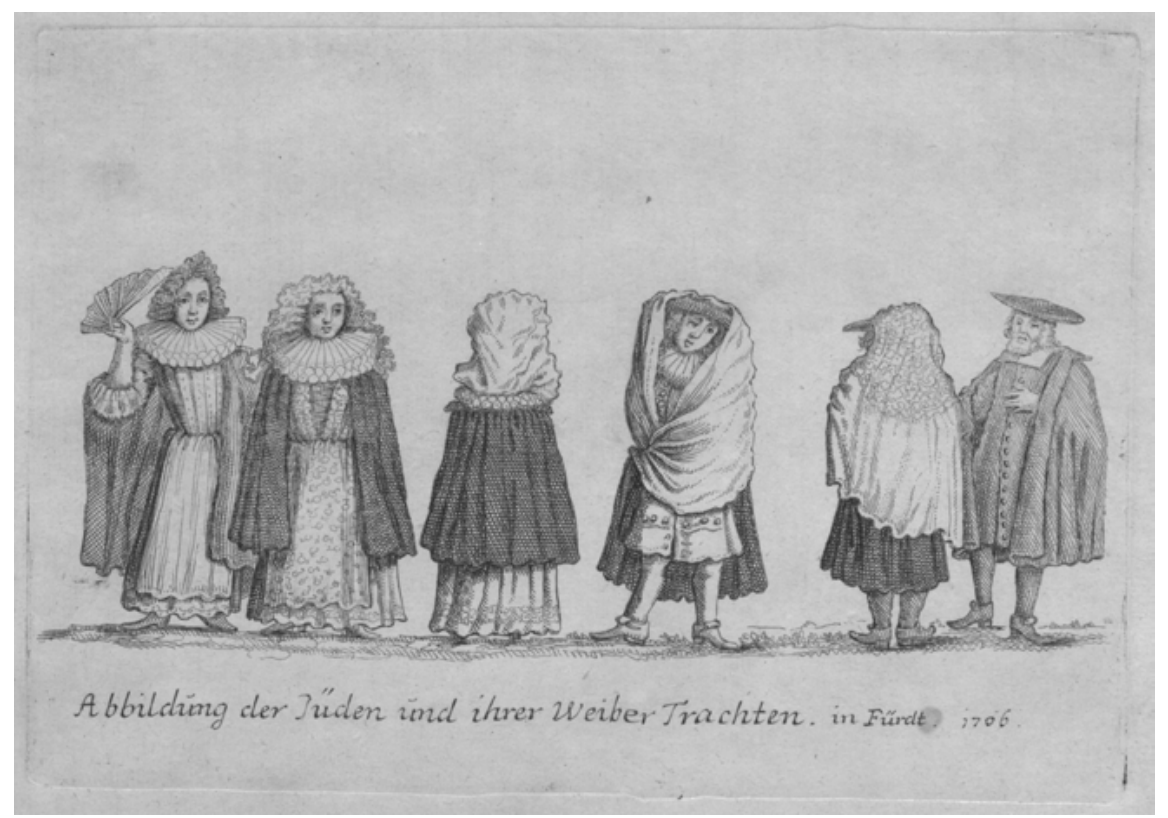

Figure 3: Johann Alexander Boener: Abbildung der Jüden und ihrer Weiber Trachten, in Fürdt, 1706. Courtesy of Stadtarchiv Fürth, Bi 791, 13a.

It seems that non-Jews in Fürth and Frankfurt, and probably beyond, would have considered a Shabbes cloak, a ruff or collar and a beret, and a winged bonnet and a ruff for women as typical Jewish attire. Jewish authorities in both towns linked the permission to wear a Shabbes cloak and a ruff to residential rights. However, it is not entirely clear for how long the cohesive force of 
belonging really convinced Jews to wear these items. Already in the sumptuary laws of the Fürth community from 1770, the Jewish elders saw the need to emphasize that no Jewish burgher was allowed to leave the house on Shabbat and holidays without the Shabbes cloak. ${ }^{50}$ Similarly, a 1786 source from Frankfurt debates the wearing of cloaks on work days and outside the Jewish street or synagogue. Here the magistrate instructed the Jewish inhabitants to always wear cloaks. A group of local Jews rejected this order and argued that they did not need such a cloak anymore to cover dirty or otherwise untidy garments, and that anyway these cloaks made them easily recognizable as Jews and thus vulnerable on the street. Moreover, there had never been an official municipal ordinance that obliged Jews to wear such a cloak. ${ }^{51}$ The relation of this cloak to the Shabbes cloak is not entirely clear, but surely the complainants in this case had no interest in being recognized as Jews in the city of Frankfurt.

\section{Conclusion}

This comparative view of early modern Jewish dress in Poland and Germanspeaking lands has shown that certain garments turned into typical Jewish attire or into Jewish garments, at least among parts of the Jewish population. At the same time, the selective evidence has shown that sartorial distinction was a delicate issue. Though both Christian and Jewish authorities insisted on a regime of visual difference, Jews were not always easily recognized by Christians. Moreover, dress was a marker of difference also among Jews of different geographical origin and social status. For the German lands, we can assume that Jews developed distinctive regional variations of dress, though many apparently wore a typical attire distinct from that of local Christians by the eighteenth century. In the relatively conservative Jewish communities of Frankfurt am Main and Fürth, the black (Shabbes) cloak and the ruff (or collar) went back to sixteenthand early seventeenth-century Spanish dress, which had fallen out of fashion. Jews of the Polish-Lithuanian Commonwealth, similarly, wore typical local garments, with differences in fabrics and embellishments, that became part of Jewish attire when they fell out of use among Polish noblemen.

50 Pinkas Fürth, D/Fu1/41, fol. 49v-50r (Central Archives for the History of the Jewish People, Jerusalem). Printed in: Litt, Jüdische Gemeindestatuten aus dem aschkenasischen Kulturraum, 265-266. Out of seven paragraphs on dress, only one pertains to men.

51 Juden Akten 171 (Institut für Stadtgeschichte Frankfurt am Main). 
For all the particular differences between Jews from Poland and the German lands, one might describe the early modern emergence of a Jewish attire in similar terms, though with different garments. The developments diverged only in the nineteenth century, when at least larger segments of Jews in the German lands participated in the development of a bourgeois society and adopted the respective sartorial style, while Jews in the Kingdom of Poland remained legally unequal and maintained a strong group identity. The majority of the Polish Jewish population, with the exception of a small segment of integrationists, continued to wear distinctive Jewish costume in the nineteenth century and beyond, even when the Russian government sought to force the Jewish population to wear what they conceived as Christian or at least non-Jewish dress. 